\title{
Perfect Match? The Practice Ecology of a Labor Market Initiative for Refugees ${ }^{\prime}$
}

I Sara Kristine Gløjmar Berthou

Ph.D., Project Manager, The Danish Society of Engineers, Denmark.

I Anders Buch²

Professor, Aalborg University Copenhagen, Denmark.

\begin{abstract}
The article investigates the case of a Danish labor market initiative for refugees with a professional engineering background. The ambition is to identify the causes and contextual elements that are active in shaping labor market initiatives directed at groups of refugees. Contemporary theories of practice are used to investigate the structures that enable, constrain, and channel the activities related to the initiative. The discussion focuses on the practice of the initiative in order to analyze ways in which activities are organized in the site. Furthermore, it sets out to investigate how the practices exist and are interconnected in ecological arrangements where practice architectures hold one another in place. The theoretical conceptualization in terms of practice, practices, practice architectures, and practice ecologies helps to explain how a seemingly ideal initiative turned out to have a little impact in bringing the refugee engineers closer to employment on the Danish labor market.
\end{abstract}

\section{KEYWORDS}

Case study / engineers / labor market initiative / practice architectures / practice ecologies / practice theory / refugees

\section{Introduction}

n early September 2015, images of approximately 200-300 refugees walking on the motorway in southern Denmark circulated the media widely. The images spurred a nation-wide debate about finances, cultural cohesion under pressure, and the sustainability of amounts. Generally, there was consensus that the situation was one of crisis, the crisis being the refugees arriving in Denmark, and an oft-used narrative about the arrivals were one of 'streams of refugees' flowing uncontrollably into the country ${ }^{1}$.

Employment is seen as the perhaps most important factor in integrating new groups of people into society. A recent report by a Danish think tank shows that 19,100 refugees holding residency permits are receiving integration benefits, since they are currently not in employment (Axcelfuture 2017). Introducing refugees and immigrants into the labor market is thus highly prioritized.

\footnotetext{
${ }^{1}$ You can find this text and its DOI at https://tidsskrift.dk/njwls/index.

${ }^{2}$ Corresponding author: buch@learning.aau.dk.
} 
At the same time, Danish technology companies lack highly skilled labor more than ever. It is expected that Danish technology companies will lack 13,500 engineers and natural science professionals in 2025 (Engineer the Future 2015). For a number of years already, companies have claimed to have had to decline orders from customers, thereby missing the economic growth potential present, due to lack of skilled labor and unsuccessful recruitment ${ }^{2}$.

Seeing these developments, the trade union, the Danish Society of Engineers (IDA) launched a pilot project in the summer of 2016, with the aim of giving refugees who hold educations as engineers the ideal preconditions to enter the Danish labor market. The aim of the initiative was to help solve both of these challenges, and provide refugees with a higher level of autonomy, empowerment, and financial security.

The initiative came to be known as the Professional Engineering Academy (PEA). It was funded by the Danish Industry Foundation (DIF), and had official support from other significant labor market stakeholders. ${ }^{3}$ It aimed to meet the lack of engineers in Danish technology companies by recruiting, training, and matching refugees with engineering degrees, with suitable companies facing challenges in attracting and recruiting enough candidates. The objectives of the project supported the objectives of the Danish tripartite agreement, which states that municipal integration strategies should be directly oriented toward industry and should secure the shortest possible way to employment for each candidate. In a period of one and a half year, and three rounds of competence programs, the projected trained 49 candidates who were selected based on their social, professional, and language skills. The competence program consisted of classes, internships, and a personal career-mentoring program.

The project had a number of positive qualitative effects. The majority of candidates expressed their satisfaction, increased feelings of empowerment, and stated that they felt better equipped and informed to navigate the Danish labor market and their job search. However, the formal success criteria that PEA expected to be able to meet, that is, matching the refugees with employers' demand for engineering labor, were not met. In total, the project established 32 unpaid internships in 25 companies. Seventeen candidates did not get internships. Whereas the original success criteria were for 30 candidates to gain employment after the finalization of the pilot project, the number at the time of writing was only nine (some of which were engineering jobs, and some part time) and two subsidized positions.

In this article, we ask why, what prima facie seemed like a well-fitted match between the supply and demand of competences, did not seem to procure the intended results.

In the labor market literature, explanation of the lower rates of labor market employment among refugees (and immigrants) are often attributed to mismatches between the supply and demand of labor (e.g., Bredgaard \& Thomsen 2018; Forslund et al. 2017). Various barriers are identified on either the supply or the demand side, or, alternatively, the lack of matching mechanisms between employees and employers are envoked as explanations (OECD/European Union 2014; OECD 2016). Some of the most important barriers pointed to in the literature are language problems (e.g., Dustman \& Fabbri 2003; OECD 2006), skills gaps and the lack of adequate education and professional training (e.g. Udlændinge-, Integrations- og boligministeriet 2016a), discrimination of refugees and immigrants among employers (e.g. Carlsson \& Rooth 2016), and refugees' lack of social networks (e.g. Behtoui 2008).

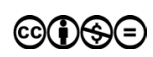


The failure of the PEA initiative to meet the formal success criteria, however, is not easily explained by these barriers. The refugees in the PEA project were highly educated with an engineering degree matching at least a bachelor level, and most had good English language skills, enabling them to work in Danish companies where English is the official company language. Furthermore, PEA had solid backing from labor market stakeholders as an initiative developed to provide matches between the refugees and the employers to compensate for the lack of social and professional network among the refugees. Lastly, we have no evidence of (overt) discrimination by employers of the PEA participants - on the countrary, many employers expressed their sympathies with the initiative and the participants. In other words, none of the traditional barriers pointed to in the existing literature can fully explain the PEA case.

We thus investigate the PEA initiative as a critical case and consider the PEA initiative as a 'most likely' type case (Flyvbjerg 2006) of successful refugee initiatives designed in a contemporary (Danish) welfare state setting. The ambition of this article is to identify salient contextual elements that can help explain why the PEA initiative, despite its promising prospects, did in fact not produce enough matches between employers and refugees. We use contemporary theories of practice (Kemmis et al. 2014; Mahon et al. 2017; Schatzki 2002; Reckwitz 2002) to investigate the practices that enable, constrain, and channel the activities that are related to the PEA initiative. In accordance with this perspective, we focus on the practice of the PEA initiative, that is, the set of interwoven sayings, doings, and relatings of the initiative, in order to analyze the practices that organize the activities in the site. Furthermore, we set out to investigate how the practices exist and are interconnected in ecological arrangements where so-called practice architectures hold one another in place. The theoretical conceptualization of the PEA initiative in terms of practice, practices, practice architectures, and practice ecologies helps us explain how the seemingly ideal PEA initiative turned out to have a little impact in bringing the refugee engineers closer to employment on the Danish labor market.

In what follows, we set out to outline the theoretical framework used. Second, we explain how the empirical material of the article was produced and the methodological considerations of our study. Third, we unfold the case through an ethnographic description. This description is supplemented by short summarizing reflections that help unpack the ethnographic material in line with the practice theoretical framework. This enables an analysis of the PEA initiative as a complex nexus of interwoven practices where the doings, sayings, and relatings are organized into practices that - in turn become enabling and restraining practice architectures for other practices. We do this in the final concluding section by conceptualizing the unfolding of the nexus of practices as a practice ecology.

\section{Theoretical Framework}

Practice theories have been developed to contrast idealized accounts of social action and social order such as homo economicus and homo sociologicus (Reckwitz 2002). The homo economicus type of social theories envision the rational and economic individual as the smallest unit of analysis, whereas homo sociologicus identify guiding norms or values as the fundamental unit. Opposed to these influential approaches in social theory, practice theories envision social practices as the smallest unit of social theory. Much 
labor market research is strongly influenced by the homo economicus type of social theories. Labor markets, and labor market initiatives, are often analyzed in terms of (mis) matches between the supply and demand of work, assuming that supplies and demands can be stimulated by economic incentives (alone) and without attending to the specificities and contextual elements of the phenomena investigated. It falls outside the scope of this article to critique the homo economicus type of social theory. ${ }^{4}$ Instead, in this article, we discuss the PEA initiative as a critical case that is in need of explanation. We suggest that contemporary theories of practice are helpful in bringing forward contextual elements that need to be considered in order to explain the unsuccessfulness of the PEA initiative in matching refugees with the demand for engineering labor.

The practice theoretical tradition has grown out of anthropology, sociology, geography, history, education, organization studies, philosophy, and more, but it is fairly recent that the 'turn to practice' has been picked up in working life studies (Buch et al. 2015; Gherardi 2015). Practice theories hold that practices are much more than an array of activities (Gherardi 2015, 15): 'It [a practice] does not consist solely in the motive that generated it or the goal that it pursues. Performing a practice activates numerous dimensions besides the instrumental one, so that functional analysis alone of practice may be useful but is reductive'. In bringing forward these dimensions, practice theories point to the contextual elements that can help us explain what the functional explanations of supply/demand/match and barriers are not able to do. The practice-based approach settles to investigate how activities are organized and enacted in time and space by practitioners in a site. ${ }^{5}$

As a site, the PEA initiative can be conceptualized as the totality of the relevant unfolding activities. This totality of relevant activities constitute practice (in the singular): the relevant doings (concrete actions), sayings (concrete meaningful utterances), and relatings (concrete ways that people relate to one another) of involved people and objects. Practices (in the plural), however, denote how activities are organized to form patterns in the doings, sayings, and relatings. The configurations of the actions, utterances, and relations - doings, sayings, and relatings - can endure in time and space and thus 'carry' constellations of activities. The practice theoretical account given here focus on how activities are organized in practices - not on the practice of individuals. It is important to notice, however, that practices are not social structures that determine actions - on the contrary, individual actions contribute to the (de)stabilization of patterns of actions by enacting the patterns or deviating from the patterns of actions.

Kemmis et al. (2014) describe how practices can be analyzed as the unfolding of doings, sayings, and relatings in time and space. The general idea is that practices manifest themselves as cultural-discursive arrangements through the constellations of sayings (e.g., what it is permissible to say, discuss, challenge, etc.), as material-economic arrangements through the constellations of doings (e.g., aspects of the physical environment, financial ressources, devision of labor, etc.), and as social-political arrangements through the constellations of relatings (e.g., organizational rules, hierarchies, community affiliations, social sympathies, and solidarities). These arrangements, furthermore, conjoin in durable constellations of activity patterns that are identifiable as practices. Practices have a dual nature in the sense that they are directed by the individual actors, but the practices also display an extra-individual dimension that consists of the historically accumulated practice traditions (e.g., professional practices, bureaucratic practices) and the materialized and/or rule-regulated arrangements that encompasses and embodies

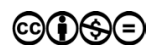


the practices (e.g., procedures to be followed, laws, and regulations). The individual and extra-individual dimensions of the practices are interwoven in the medium of language (sayings), activity and work (doings), and power/solidarity (relatings) to form the unity of social practices.

As practices unfold and intersect, they tend to become the 'environment' for other practices. The interlinkage of cultural-discursive, material-economic, and social political arrangements shapes practices and gives them a site-specific practice architecture. The practice architecture thus mediates the enactment of practices by forming the necessary (but not sufficient) condition for the continuation of the practices. Bundles of practices thus become the environment for other practices, and this interconnection will eventually establish a site-specific practice architecture that constitute and prefigure (necessary) conditions for the enactment of practices. The following explanation of this mechanism emphasizes the complex constitutive feature of practice architectures:

The practice takes up sayings, doings and relatings already to be found in the site, orchestrates and engages with them, and leaves behind in the setting particular kinds of discursive, physical and social traces or residues of what happened through the unfolding of the practice. These traces or residues are left not only in participants' memories and interactional capacities but also in the practice itself as a site for sociality. Some of these residues become part of the practice architectures of the setting and are newly encountered by others who subsequently inhabit it-for example, when tomorrow's class discovers where the chairs were left in the classroom by today's students, or when new contributors to a debate in the research literature of a field find that the field has 'moved on' from the debates of earlier years. (Kemmis et al. 2014, 34, emphasis in the original)

Practice architectures thus enable and constrain other practices. One set of practices can become the practice architecture for another set of practices and vice versa. This coconstitutive and reciprocal relationship between practices have consequences for the way we think about complex social phenomena that include multiple practices. Kemmis and Mutton suggest that we envision this complex interconnection of practices as ecologies:

By ecologies of practice we mean distinctive interconnected webs of human social activities (characteristic arrangements of sayings, doings and relatings) that are mutuallynecessary to order and sustain a practice as a practice of a particular kind and complexity. (Kemmis \& Mutton 2012, 15)

Ecologies of practices include bundles and larger constellations of practices that are characterized by their interdependence. In the ecologies, the involved practices 'feed' one another (Kemmis et al. 2014, 47) in the sense that they are mutually vital for one another - the output of one constellation of practices become the input for another constellation of practices. In these complex ecologies, some practices tend to become 'resilient' and 'ingrained' in the practice ecologies and thus difficult to alter or replace by other practices. On the other hand, changes in one constellation of practices might eventually 'suffocate' other practices and lead to major transformations in the ecologies of practices. The point is that practice architectures only provide necessary, but never sufficient, condition for the reenactment of practices. 


\section{Materials and Methods}

The overall framework for the data used in this article is a qualitative in-depth case study in the PEA initiative. Specifically, we see the PEA initiative as a critical case (Flyvbjerg 2006: 230) of a Danish integration initiative working through labor market tools. While a typical or average case is never the one richest in information, the nontypical or critical case often provides more information because it activates more actors and reveals more significant insights in how change happens (Flyvbjerg 2006: 229).

In addition, from both an understanding-oriented and an action-oriented perspective, it is often more important to clarify the deeper causes behind a given problem and its consequences than to describe the symptoms of the problem and how frequently they occur. (Flyvbjerg 2006:229)

A critical case aims 'to achieve information that permits logical deductions of the type, "If this is (not) valid for this case, then it applies to all (no) cases"” (Flyvbjerg 2006:230). This is not to say the case is generalizable in a statistical sense, but rather to point to the fact that it is analytically generalizable: the case sheds light on a number of central challenges and conditions of many integration projects. In the PEA initiative, it seemed at first glance that conditions and elements were in favor of a successful outcome, most importantly the motivated and highly skilled participants in the PEA program, support from major labor market stakeholders, and the demand for more technically skilled engineers in the Danish labor force. The PEA initiative is thus interesting, as it contains information likely to generate analytical generalizations when examined closer.

The collection of data consisted of integral and close observation and participation in the PEA initiative over a period of a year and a half. More specifically, we observed and participated in the entire project life time, including the process of developing the PEA initiative, designing the competence programs, recruiting partner companies, matching those companies with participants, and communicating and evaluating the project. Concretely, these observations took place through continuous participation in relevant meetings, continuous written correspondences with people inside and outside of the project, as well as informal and formal verbal conversations. In addition to this, the data draw on a large body of meeting minutes, public communication material, participant evaluations and correspondances, as well as other project documents.

To ensure the formal documentation of central stakeholders, we carried out indepth ethnographic interviews (Spradley 1979):

- Interview 1 with interlocutor PP: PEA Project owner: the executive in IDA who originally came up with the project idea, applied for funding, conceptualized the project and hired the project managers.

- Interview 2 with interlocutor PM: PEA project manager: One of two project managers in PEA.

- Interview 3 with interlocutor CR: Company representative: A central company partner who hosted a PEA intern, whom they later hired.

The ethnographic interview is characterized by being explorative and practice-oriented (Gherardi 2012). This means that rather than focusing on narratives and interpretations the interwiever asks the interlocutor to explain how phenomena unfold or unfolded,

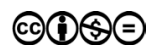


rather than ask them why or for the interlocutor to interpret them (the so called 'interview-to-the-double', Nicolini 2009).

As one of the authors were part of the project team as the other of two project managers, we had a unique insight into all processes taking place in the project. The project managers conceptualized, developed, and implemented the PEA initiative in its different phases and interacted with the relevant stakeholders and participants on a regular basis. This involved dialogue with companies about internships, negotiations with municipalites about regulations and procedures for participation in the PEA initiative, and promotion of the initiative in general. The study is not based on classic action research (e.g., Kemmis et al. 2014b; Nielsen \& Nielsen 2010), however, but a retrospective analysis of the material in question. While personal involvement in the site under study entails a number of important reflections on legitimacy and ethics, we follow Alvesson (2003) in seeing this involvement as a resource as much as a liability. In his description of the self-ethnography, he states:

A self-ethnography is a study and a text in which the researcher-author describes a cultural setting to which s/he has a 'natural access', is an active participant, more or less on equal terms with other participants. (Alvesson 2003:174)

The self-ethnography shifts the emphasis slightly from classic participant observation to observing a participant (Alvesson 2003:174). This allows the researcher to see the phenomena under study in its every day setting, not just accounts of it in interviews, which may often be colored by social norms, expectations, and interests:

Ethnographies have some clear advantages. Observations of naturally occurring events avoid - or, more usually, reduce - the researcher's dependence of the accounts of respondents. The researcher may discover aspects which interviewees may be unaware of or which, for other reasons, they find difficult to articulate. (Alvesson 2003:172)

The self-ethnography approach gave us the advantage of having better access to interesting and rich empirical material unfolding over a longer period of time, which would often not be possible due to limited resources and time.

Despite these advantages, the intrinsic role of one author in the project raises a few issues worth mentioning. First, is the issue of studying a process one has sought to shape and influence: The challenge here lies not so much in the idea of obstructing some kind of pure data material (an idea that has long been abandoned in most social sciences). On the contrary, the situation provided a chance to actively engage with the takenfor-granted ideas and the tacit knowledge of the project. Second, is the issue of a potential bias in disseminating the project in a particular (favorable) light. Such potential bias is often associated with a certain pressure to maintain relations in the researcher's own setting, but it is also the case that diplomacy is certainly not foreign to other kinds of qualitative research in which healthy relations in the field are crucial. Since the intention of the paper is to understand why the project was in fact not a formal success, we pose that this is indeed not a significant issue in this particular research methodology. Furthermore, one author has had a more external perspective on the material, offering a unique combination of internal and external perspectives. 


\section{The PEA initiative}

In September 2015, the Danish prime minister, Lars Løkke Rasmussen, hosted what he referred to as a civil society summit, at his official residence Marienborg. In his own words, he intended to test the call, from managing director of the Confederation of Danish Industry, to get newly arrived refugees into the labor market quickly. The prime minister wanted to make sure the good intentions were transformed into action:

Somebody out there must accept ownership [...] Some of the company managers who are worried about the adds ${ }^{6}$ or the tone and claim that diversity is good, must take responsibility now by opening their companies to these people - for instance by offering them internships. (Berlingske 2015)

The summit became the starting point for a range of initiatives. Upon its completion, the DIF launched a call for project funding applications with a total amount of 50 million Danish kroner to distribute. They called for projects that could:

[turn] a challenge into a profit. The industry lacks labour force while thousands of people are arriving in Denmark. If we can succeed in making newly arrived refugees a valuable part of the labor force much faster than is the case today, preferably right away, we will have gotten far - in terms of both competitiveness and integration (Scheiby, board director in the Danish Industry Foundation).

The focus of the call was mainly on providing the industry with labor force however, and less so on integration. As such, the goal of the call was

that especially newly arrived refugees get jobs in the private sector and thus meet the increasing lack of skilled, but also unskilled labor several places in the country. The intent [of the call] is to bring companies and municipalities closer together so the problem with lack of labor force in the private sector can be solved?

At the same time, several people working at the headquarters of IDA were watching the current situation unfold with considerations of what could be done: 'It was during those days where everyone were talking about the refugees on the road and everyone was thinking "what can I do"' (interlocutor PP). Consequently, a small group in IDA put together a project application for funding for the 'IDA Refugees Professional Program'. With its 110,000 members, IDA is one of the largest trade unions for academics in Denmark. Approximately 160 people work at its headquarters offering career counseling, legal assistance, events, networks, policy work, and assuring individual and collective agreements. While the trade union works in the interests of its members within a number of key areas, it has no political affiliation. The subject of refugees, on the other hand, is a highly politisized area and so the initial phase of the PEA initiative unfolded unofficially and on a voluntary basis for the people involved since

... it was not part of IDA's raison d'etre to take a role in this. We risked that somebody might perceive it as something political, which is always something to be aware of: At the 
same time we knew, that it was important that we act and took responsibility and not just had an opinion and talk about it (interlocutor PP).

In the work with shaping and developing the project, a number of relevant stakeholders from fields related to refugees were included, among them researchers, integration experts, Red Cross, the Danish Refugee Council, and voluntary groups. During this process, the group dropped the idea to do work in asylum centers and moved toward an idea of selecting talented refugees who could pose as role models for other newly arrived engineers. Hearing about the call from DIF, the group contacted the contact person to enter into a dialogue about the application for funding:

Luckily, she was very accommodating and was a very good sparring partner in terms of helping us frame the project so that it fitted the purpose of the DIF. [...] What happened when we talked to DIF was that the framing of the project became much more target oriented in terms of - what is it that the companies need. And that was what we had to support and then help the candidates become what the companies need, to say it like that. So everything that had to do with, how to put it, the more classic humanistic values were set aside and it became more business, to put it like that. Not business in the sense that someone should profit off of it, but the main question became, what is it actually our society needs. And that was quite healthy I think- because that was also needed (to sell it) internally, so that it was not only charity, but actually something where we could genuinely help fulfil a need (interlocutor PP).

In this way, the focus of the initiative changed from being predominantly an integration initiative to a labor force initiative. This change was well aligned with the need to make the project fit IDA as a professional trade union: 'We had to find the angle that fitted into IDA. [...] So, we ended up talking about it like - to realize all possible potential. At the end of the day what's important is - know your organization' (interlocutor PP). The final project concept was launched in June 2016 with funding from the DIF. It had the aim of minimizing the gap between newly arrived engineers and the Danish labor market, and thus decreasing the lack of engineers in Danish tech companies. It was to do so, through three competence programs of each four months, designed as an incubation training intended to improve the social, cultural, and professional skills of the participants, thus minimizing the distance to the labor market. Each competence program contained classes on the Danish labor market, Danish work place culture, the various sectors of the industry, the skills in demand, as well as project management and professional English terminology. Moreover, the program were to contain internships in Danish tech companies, and each participant were assigned a personal career mentor for personal coaching. Each round of the competence program could hold up to 30 participants who were screened and accepted based on their language level, professional profile, and motivation level.

\section{Refugees or newly arrived engineers: Framing the Professional Engineering Academy}

At the heart of this new project was the deliberate intent to see the participants as resources. This meant that after the two project managers began to develop and run 
the project, the initial name IDA Refugees Professional Program was changed to the final Professional Engineering Academy and the methodology explicitly defined as a resource-oriented and acknowledging approach to the refugees, in which professional identity was highlighted over refugee status or history. At the core of the methodology was the recognition of the many ways the participants would often be positioned before and on arrival in Denmark, in various contexts, including as refugees, receivers of welfare benefits, financial burdens, traumatized people, potential criminals, clients, and objects of voluntary efforts. Trying to challenge these widespread perceptions, the project attempted to include them in a professional 'us', by meeting them as role models selected among other talents, thus welcoming them into a large professional network with Danish peers in PEA.

Specifically, the professional identities and abilities of the candidates were emphasized and developed throughout all the elements of the competence program. When signing up for the project, applicants were encouraged and supported to get their education formally recognized at Danish Agency for Science and Higher Education. Once accepted, the participants received individually adapted guidance and coaching from personal career mentors and a practice-based competence assessment in the internships integral to the competence programs. Furthermore, participants took part in individual coaching in order to gain professional confidence and the classes intended to develop an awareness of the extent of professional competences, and a vocabulary to disseminate those. The project differed significantly in these aspects from many similar services from public and private job centers.

The fact that PEA was organizationally placed in IDA was thought to enable a unique role vis-à-vis the participants, which could help make this new approach possible. Whereas most interactions with the authorities entailed a long list of demands and rules, participation in PEA was voluntary and based on their professional backgrounds rather than their status as refugees:

Being part of PEA was the first time I felt like an engineer since I arrived in Denmark. (Participant in PEA)

Our greatest strength is definitely that we are a professional community that acknowledges these people. We are not in a power position, like the private job consultancies or other integration bodies - this is a professional community. The acknowledging perspective, it cannot be repeated enough, is what makes us something else than status quo. We are something else. I know that this is something very positive for all of our participants. We have some barriers, but it is clearly the greatest strength that we are IDA and we don't have this power over them. (Interlocutor PM)

As will be evident (see below), this attempt at a resource-oriented methodology would be challenged and negotiated as other practices and agendas came into play in the interaction between PEA and a number of actors. The two project managers from IDA recognized that the initiative was potentially challenged by the cultural-discursive arrangements that dominate practices of integrating refugees, and they made an effort to change these arrangements by framing the PEA initiative in terms of a more resourceoriented discourse in the semantic space. This work of articulation was meant to direct the initiative at practices of recruitment, professionalism, and releasing the potentials of 
skillful engineers, and to avoid affiliation with practices associated with culture differences, naïve humanism, ethnicity, skills deficits, and clientization.

\section{Getting PEA into the public domain}

The attempt to get PEA into the public domain happened at first, in the negotiation around how to communicate the project. When the project had just received funding, the media took a very active interest in the project. Several newspapers and TV channels wanted to cover the 'positive story'. This media coverage was significant in catalyzing a number of opportunities, which the project was much dependent on in its early phase. Recruiting candidates happened through contact with municipalities and volunteers, making it important that these would hear about the existence of the project, and as such, media attention became an important factor. In the communication strategy of the project, it was intentionally emphasized that the participants were 'newly arrived engineers' or 'engineers with refugee backgrounds', rather than merely refugees. This was quickly challenged by the media contacts who wanted to emphasize the 'refugee perspective' in order to communicate the positive story:

I think it has to do with the fact that we started at the time we did: There was a notion in society that something needs to be done for refugees. So, for them [the journalists] it was an opportunity. They saw that it would be promoted well because it would speak into a narrative already existing in society. I think that was the main thing: From a press point of view, it was the best way to sell the story to more newspapers, and it also meant that many newspapers wanted to write about us, so we overlooked it in order to get the PR that we needed to get started. (Interlocutor PM)

The attempted effort to support the PEA initiative by mobilizing cultural-discursive arrangements from the resource-oriented narrative originally suggested thus seemed to be counterbalanced by the prevalent social-political arrangements. The PEA initiative needed to be publicly exposed in order to obtain momentum - to recruit participants, to get attention from relevant companies, and to gain internal visibility (in relation to IDA's members) as a successful project in IDA. The practice architecture of the media was prefigured to focus on 'hot' political agendas, and the 'refugee' issue was much easier to communicate than the resource-oriented narrative. The social-political arrangements were configured by the role of IDA (an interest group of professionals), the ongoing political agendas at the time, and the practices of journalists who wanted to cover 'hot' political agendas.

\section{Interacting with municipal administrators and job consultants}

The interaction with the municipalities gave rise to changes in the project as well. The PEA participants were all part of integration programs in their respective municipalities, as part of the integration law in Denmark. This meant that they were subject to a specific legal framework, determining their daily activities to a wide extent. Just before the beginning of PEA, the government introduced changes in this legal framework. This 
entailed a 'targeting of the integration program towards the labor market, with increased use of company targeted activities' (Udlændinge-, Integrations- og boligministeriet 2016) while '...the municipalities and companies that attain the best result with getting refugees employed are rewarded with result grants and bonus' (ibid.). Specifically, this meant that potential participants in PEA were required to take part in activities with 'an unambiguous job targeted focus' (ibid.) from the first month after gaining residence permit and moving from an asylum center to a municipality. Furthermore, a maximum of 6 weeks could pass between company-targeted activities such as internships or subsidized employment schemes. To make sure the competence program adhered to these new legal requirements, the PEA project managers entered into a dialogue with Local Government Denmark ${ }^{8}$ early on, who assessed that it would be well within the frame, since focus was on employment.

There were wide differences in how these legal frameworks were interpreted, negotiated, and practiced in the different municipalities, however. After conversations with a number of municipalities, who all interpreted the changes in different ways, it was established that the competence program in PEA was indeed not valid as 'company oriented' in itself. At the same time, there could be no more than 4-6 weeks between company-oriented activities, so the internship had to be moved to the beginning of the competence program.

There was a clash with the municipal focus on employment. The main agenda in the municipalities are employment. Also in society at large. They [the refugees] should be selfreliant. So, we clashed with a societal idea that they must be employed as fast as possible, and with these changes in the municipalities, but also higher up, in ministries, and so on, that they have to work - and it does not matter if the work is relevant to their vocation or not (Interlocutor PM).

The adjustment made the program fit within the legal frame, but in turn worked against the wish of the partner companies who wanted the participants to be socially, culturally, and vocationally trained before the internship in order to create the best conditions for a future professional match. Instead, the participants had to be sent into internships quite early in the competence program, often making the integration into the companies slower and more complicated.

The increased focus on employment further resulted in several potential candidates for the program having become self-supporting through unskilled employment or internships outside of their vocation, meaning that the pool of potential candidates became significantly smaller. Moreover, a law was introduced whereby all recipients of welfare benefits had to have a minimum of 225 paid hours of employment a year, in order to receive unemployment benefits. This meant that several participants had to drop out of the program in order to find manual labor jobs to accumulate these hours, to avoid losing part of, or all of their subsistence income. Altogether, these legal frameworks and the continuous changes resulted in much smaller groups of participants in each competence program. Rather than the initially estimated 25-30 participants in each of the three rounds, the numbers dropped to 24, 15, and 10, respectively. In a way then, the legal changes meant that any kind of connection to labor market trumped more long-term solutions whereby refugees could get back into their own skilled vocations.

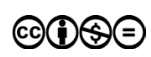


The material-economic arrangements of the site, that is, the economic short-term incentives of the municipalities and the legal framework that regulated integration programs, also made it difficult to stick to the original resource-oriented narrative of the PEA initiative. The refugees were first and foremost clients in the integration programs of the municipalities, and the participation of the clients in the PEA initiative was made contingent on its ability to comply with law enforced regulations and underpin the short-term objectives of employment. The PEA initiative had to comply with these terms and witness a drop in the number of participants. The material-economic arrangements of the site thus significantly changed the activities related to the PEA initiative - it came to focus more on short-term employment rather than long-term professional training.

\section{Engaging and committing companies}

The perhaps most important stakeholder was the companies, which PEA depended on particularly for internships for the participants. Early on, about five companies agreed to become partners in the project, thereby committing to collaborate in the development of the program, to offer unpaid internships and help assess and evaluate the participants. It would prove very difficult, however, to form enough relations to the large number of companies needed to establish internships for all the participants. In the total 1 year and a half, the project ran, 32 of the 49 participants in the program had internships, while 17 others never did internships in any company.

The project made use of a number of strategies to reach potential companies, including the use of informal and formal networks in IDA, the use of social media, personal contacts, unsolicited calls and e-mails, and reliance on the stakeholders in the project, including the Plastic Federation, a number of industry councils, and interest organizations. When interacting with the potential partner companies, PEA primarily wished to emphasize the professional background of the participants, in order to make wellfitted matches focused on recruitment. In this process, arguments would be about the lack of engineers in the industry and thus how the participant in question might create value for the company with their technical competences. The most important tool in this regard was the $\mathrm{CV}$ of the participant. In each of the three rounds, however, as rejections from companies increased, the strategy changed to get more internships established. It became evident that when a different language was used to introduce the project and its participants, it generated more interest. While interacting with HR-departments and department managers, the most predominant arguments were whether candidates were 'billable' and rejections had to do with efficiency and profitability: not being able to assign resources to train candidates. Instead, when emphasizing that the project was for refugees and about creating value for newly arrived engineers, who needed a chance to get a foothold on the Danish labor market, more internships were established. Since many companies work with a corporate social responsibility strategy (CSR), and the CSR departments or strategies had different frameworks and independent resources, it was easier to have resources specifically assigned to a refugee intern, and the company could check boxes to do with taking societal responsibility.

How will we ever integrate anyone, if we don't invite them inside? So, if it hasn't been a benefit for [Company name], then at least for society (Interlocutor CR) 
The internship brought value as we are proud to be able to help a human being who need help getting a foothold on the Danish labor market. We hope this will benefit both Denmark and the labor market in the long run (Email from company representative)

First of all, we want to help integrate refugees. Its part of our CSR-profile. Secondly its about money and the need for competences here. (Email from company representative)

Therefore, adjustments were often made and the conversations changed character from being about matching, onboarding, and interviews, to 'giving the candidate a chance' to get a foot in the Danish labor market, taking responsibility, and being inclusive. Part of the challenge with maintaining a strict employment focus in the interaction with the companies also had to do with the constitution of the participants' professional background and competences. Educated in countries whose labor markets significantly differ from the Danish labor market, their skills were targeted different tasks and procedures. This meant for instance that the tools they used were different, challenges particularly revolving around the use of IT, their routines and embodied know how, and their lack of understanding of the historical context. For instance, a participant urged a consulting engineer firm working with sustainability to tear down a range of old houses, which were to be refurbished sustainably.

To begin with, I thought perhaps Danes were poor, since they do not decorate their buildings. But now I know its just because the simple look is prefered in Scandinavia. (Participant in PEA)

This lead them to conclude that his technical know was culturally grounded in a way that were too far from where it needed to be in order to hire him. Other clashes had to do with the deeply engrained idea of hierarchy. This had to do with more than just ideas of how to receive and take orders, but also about the very way of working in Denmark, where companies asked for pro-activity, initiative and independency: all ways of being that the participants experienced as very challenging, having spent years in highly hierarchically structured work environments. The realignment with Danish ways of doing engineer work was challenged by the difficulty to gain access even to unpaid internships.

One of the consequences of this was a change in focus as regards the participants, from employment to assessment:

It probably changed from an employment focus to an assessment focus and a focus on giving these people some tools to get into vocationally relevant employment at a later point in time. I never had an idea that we could do magic but I definitely had the expectation that they would get a lot closer to employment through our program, and that they would get a much better chance. Now it's more about giving them an understanding of their own competences, and how to navigate. It is a much longer process than we intended for. JGR

As a result, the competence assessment approach was changed so that the candidates would spend longer time in internships, in order to get practically based assessments of their skills that they could use to try to get further education or courses from their municipality, in order to get closer to employment. This was often almost impossible, since the municipalities worked under very limited budgetary limitations. Moreover, 
they already had educations, which meant that they could often not be granted more courses.

The candidates who were ready for ordinary employment in terms of technical knowhow still experienced challenges, however, with their language levels and the culturally different work structures. Specifically, the candidates discovered that Danish workplaces are often project oriented and based on independent and pro-active working, whereas the labor markets they came from generally were task oriented and hierarchically structured. This made it difficult in terms of salary placement since they did not fit smoothly into the current levels used. This meant that several candidates either ended up in under-paid jobs or were rejected because it was too difficult to find a fair wage level. In other instances, the candidates would be offered subsidized positions, which would give the company a period of time with less expenses in which they could train the person in question.

The practices prevalent in the companies add a significant input to the conducive practices of the PEA initiative. The prevalent practices of the companies eventually become a significant part of the practice architecture of the PEA initiative. The fact that the refugees were seen as not immediately 'billable' in commercial projects made it difficult for the PEA initiative to proceed with its resource-oriented approach. It was easier to establish relations via the CSR practices adopted by HR-departments in companies. But taking this avenue fore fronted the refugee status of PEA participants at the expense of their professional status. The PEA initiative eventually shifted its focus and became more preoccupied with issues of competence assessment, preparation for further education, etc. - a focus not easily mediated amidst the social-political and material-economic arrangements of the site.

\section{The practice ecology of the PEA initiative}

The crude description of the activities and happenings of the PEA initiative given above not only brings forward the situated and complex character of some of the arrangements in the site, but it also shows how agency is distributed and interwoven among actors, materiality, and discourses. Over time, and by the mediation of institutional practices, legal, economic practices, and discursive practices, the determination of activity falls into place in both intended and unintended ways. In the unfolding of events - both nonintentional occurances and intentional activity - the site appears as the determining context of activities. Change and/or stasis transpires in the site through temporal-spatial activity continua of practice-arrangement boundles, and the site finds its determination as it happens in the present. The practice theoretical account of the development and happenings of the PEA initiative thus aims to give a contextual account of the complexities of the situation, as it unfolds as a site composed of cultural-discursive, materialeconomic, and social-political arrangements.

In our discussion of the PEA case, we not only wish to point to the inadequacy of understanding labor market initiatives in simple economic and rational terms of supply, demand, and match, but more importantly, we want to point to deeper causes in the situation under study (Flyvbjerg 2006: 229), namely how practice-arrangement boundles interconnect and prefigure/shape activities in architectures of practices and practice ecologies. Our research contribution thus points to some fundamental causes that are active in organizing activity in labor market initiatives for refugees in the Danish welfare state. 
Our ethnographic research has unfolded the sayings, doings, and relatings manifested in activity within the site. At the outset of the PEA initiative, we observed how the initiators of the initiative in IDA strived to engage with the refugee crisis by articulating the initiative in terms of a resource-oriented narrative. However, this articulation work was not successful. The cultural-discursive arrangement of the site was not easily transformed. Other practices enacted by reporters from the public media needed to frame the PEA initiative as a refugee initiative that stressed the refugee status of the participants more strongly. These communicative practices are vital for IDA as a professional body with a policy agenda and cannot be ignored without disrupting IDA's institutional position within the social-political arrangements of the site. Furthermore, downplaying the communicative practices that articulate PEA as a refugee initiative would also marginalize it in relation to funding agencies and regulative practices in the municipalities. The material-economic arrangements of the site thus did not easily accommodate a resourceoriented narrative.

As legislation, administrative incentives, and administrative practices in the municipalities changed to focus more on company-targeted activities, the material-economic arrangements of the site reshaped the PEA initiative in significant ways. Participants had to spend more time in internships in the early stages of the program at the expense of a professional training and introductions to the Danish cultural practices. Similarly, the companies short-term demand for 'billable' hours prevented the participants to enter the companies on regular terms. Company entrances had to be channeled through CSR programs that focused more on the social responsibility of the companies than on participants' resources. The social-political arrangements of the site thus also tended to configure the participants in terms of their refugee status.

According to the practice theoretical perspective, the genealogy of the PEA program and its eventual (in)ability to bring the participants in non-subsidized employment must be explained in light of the mediating cultural-discursive, material-economic, and social-political arrangements of the site. These arrangements, in turn, are generated by a history of reenactments of sets of practices and they meet new practices - such as the resource-oriented narrative practices - in the form of a reified practice architecture. The successfulness of the new practices depends on their ability to coinhabit and coexist in the practice architecture - or ultimately to transform the entire practice architecture to better promote the objectives of the new practices. Alternatively, the failure of the new practices will show, as they are not able to coexist with the dominant practices of the practice architecture and eventually are not reenacted. The practice architecture of the site thus enables and constrain the way new practices can unfold in the site. Practices thus 'feed' on one another, prefigure one another, and enable/constrain one another in reciprocal ways. Kemmis et al. (2014a) argue that a productive way of thinking about this interrelatedness and interdependense of practices is by envoking the concept of ecologies of practices.

Envisioning the PEA initiative through the lens of practice theory and adopting an ecological perspective on the transformative processes that shapes and reshapes the practice architectues of labor market initiatives can help us explain why what prima facie seemed to be a 'most likely' type case of successful refugee initiative did not turn out as successful.

The PEA initiative prima facie seemed to be a promising labor market project. On the demand-side, employers emphatically expressed a wish to recruit more engineers,

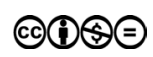


and significant labor market stakeholders supported the PEA initiative in the hope that refugees with technical educational background could supply the asked for working capacity. On the supply-side, a number of refugee engineers were identified and resources were established to prepare them for employment. Furthermore, relevant authorities, institutions, labor market stakeholders, and companies were mobilized to ensure that the match between demand and supply was met successfully. All in all a very promising setup. However, the outcome of the PEA initiative was disappointing - only very few refugees obtained employment in engineering jobs.

Our ethnographic study of the practice ecology of the PEA case helps us explain this outcome:

- The resource-oriented narrative of the PEA initiative was not accommodated by the cultural-discoursive arrangements of the practice architecture. Even though the project started off aligning the narrative of the PEA initiative with the business discourse of the companies' demands for engineering competences, the cultural-discoursive arrangements of the site made it difficult to stick consistently to this narrative. The refugee status had to be brought forward to get the PEA initiative into the public and establish contacts with the relevant stakeholders and identify the potential participants. The media needed to communicate PEA in terms of the refugee crisis - even though they regarded the PEA initiative as a 'positive story' in the context of the crisis.

- The material-economic arrangements of the practice architecture made it difficult to stick to PEA's original ambition of preparing professionally resourceful engineers to enter the Danish labor market. The economic incentives influenced the municipalities to bring refugees into employment without delay - irrespectively of the professional status of the jobs the refugees were introduced to. Many refugee engineers were thus put into unskilled jobs and had to drop out of the program.

- The social-political arrangements of the practice architecture also made it difficult to fulfill the ambitions of the PEA initiative. The general political ambition that refugees should become self-supported quickly, regardless of whether they made their income through skilled or unskilled jobs, sidestepped the industry aim to bring more engineers in contact with Danish companies.

The contextual elements of the practice ecology found in the site thus helps explain the unsuccessfulness of the labor market initiative (in regard to its formal success criteria).

On a theoretical level, the theory of practice architectures and practice ecologies have helped us conceptualize the PEA case in its situated complexity by framing the interplay of practices and practice architectures in relation to the cultural-discursive, material-economic, and social-political arrangements of the site. Furthermore, the practice perspective has provided the analytical resources to engage with the empirical level and actual happenings in the site. For example, our analysis can help prompt and qualify new (research) questions in relation to labor market initiatives, such as: What are the consequences of reenacting existing work practices? (How) does the existing practice architectures of the site of intervention support/counteract the intended results? What is the the most likely space for successful intervention in the site?

The ambition of this article is explanatory and analytical. However, practice theoretical accounts also have transformatory potential, and the theoretical framework can 
be mobilized to substantiate interventions (Mahon et al. 2017), action research (Kemmis 2014b), and policy regulations (Jonas \& Littig 2017, Shove 2010). It falls outside the scope of this article to elaborate on the potentials of practice theory to support efforts of designing, promoting, or regulating labor market initiatives, but we encourage future (action) research to investigate the viability of practice theoretical approaches as alternatives to the predominant homo economicus social theory of contemporary labor market policy.

\section{References}

Alvesson, M. (2003) Methodology for close up studies - struggling with closeness and closure, Higher Education 46: 167-193. doi: https://doi.org/10.1023/A:1024716513774.

Axcelfuture (2017) Anbefalinger, der kan styrke beskæftigelsen blandt nytilkomne flygtninge og familiesammenførte [Recomendations to strengthen employment amongst newly arrived refugees family reunited]. Axcelfuture.

Bredgaard, T. \& T. Lund Thomsen (2018 - this issue). Integration of refugees on the Danish labour market, Nordic Journal of Working Life Studies.

Behtoui, A. (2008) Informal recrouitment methods and disadvantages of Immigrants in the Swedish Labour Market, Journal of Ethnic and Migration Studies 34(3): 411-430. doi: https://doi.org/10.1080/13691830701880251.

Buch, A., V. Andersen \& L. Klemsdal (2015) Turn to practice within working life studies, Nordic Jornal of Working Life Studies 5(3a): 1-11. doi: https://doi.org/10.19154/njwls. v5i3a.4830.

Carlsson, M. \& D.-O. Rooth (2016) Employer attitudes, the marginal employer, and the ethnic wage gap, Industrial and Labor Relations Review 69(1): 227-252. doi: https://doi. org/10.1177/0019793915601630.

Dustman, C. \& F. Fabbri (2003) Language profeciency and labour market performance of immigrants in the UK, The Economic Journal 113: 695-717. doi: https://doi. org/10.1111/1468-0297.t01-1-00151.

Forslund, A., L. Liljeberg \& O. Årslund (2017) Flykting- och anhöringinvandrades etablering på den svensa arbejtsmarknaden [Refugees and affiliated refugees entry at the Swedish labor market], IFaU Rapport 2017:14. www.ifau.se.

Flyvbjerg, B. (2006) Five misunderstandings about case-study research, Qualitative Research 12(2): 219-245. doi: https://doi.org/10.1177/1077800405284363.

Gherardi, S. (2012) How to Conduct a Practice-Based Study. Problems and Methods, Cheltenham: Edward Elgar.

Gherardi, S. (2015) How the turn to practice may contribute to working life studies, Nordic Journal of Working Life Studies 5(3a): 13-25. doi: https://doi.org/10.19154/ njwls.v5i3a.4831.

Heidegger, M. (1927/1979) Sein und Zeit [Being and Time], Tübringen: Max Niemeyer Verlag Tübringen.

Jonas, M. \& B. Littig (2017) Praxeological Political Analysis, New York: Routledge.

Kemmis, S. \& R. Mutton (2012) Education for sustainability (EfS): practice and practice architectures, Environmental Education Research 18(2): 187-207. doi: https://doi.org/10. 1080/13504622.2011.596929.

Kemmis, S., J. Wilkinson, C. Edwards-Groves, I. Hardy, P. Grootenboer \& L. Bristol (2014a) Changing Practices, Changing Education, Dordrecht: Springer.

Kemmis, S., R. McTaggart \& R. Nixon (2014b) The Action Research Planner. Doing Critical Participatory Action Research, Singapore: Springer. 
Malhon, K., S. Francisco \& S. Kemmis (eds.) (2017) Exploring Education and Professional Practice Through the Lens of Practice Architectures, Singapore: Springer.

Nicolini, D. (2009). Articulating practice through interview to the double, Management Learning 40(2): 195-212. doi: https://doi.org/10.1177/1350507608101230.

Nielsen, B. \& Nielsen, K. (2010) Aktionsforskning [Action research], in S. Brinkmann \& L. Tanggaard: Kvalitativ metode. En grundborg [Qualitative Methods. An introduction], 97-120, København: Hans Reitzel.

OECD/European Union (2014) Matching Economic Migration with Labour Market Needs, Paris: OECD. www.oecd.org.

OECD (2016) Making Integration Work. Refugees and Other in Need of Protection, Paris: OECD. www.oecd.org.

Reckwitz, A. (2002) Toward a theory of social practices. A development in culturalist theorizing, European Journal of Social Theory 5(2): 243-263. doi: https://doi. org $/ 10.1177 / 13684310222225432$.

Schatzki, T. (2002) The Site of the Social. A Philosophical Account of the Constitution of Social Life and Change, Pensylvania: Penn State Press.

Schatzki, T. (2005) Peripheral vision. The sites of organizations, Organization Studies 26(3): 465-484. doi: https://doi.org/10.1177/0170840605050876.

Schatzki, T. (2010) The Timespace of Human Activity. On Performance, Society and History as Indeterminate Teleological Events, Lexington: Lexington Books.

Shove, E. (2010) Beyond the ABC. Climate change policy and theories of social change, Environment and Planning A 42: 1273-1285. doi: https://doi.org/10.1068/a42282.

Spradley, J. (1979) The Ethnographic Interview, Fort Worth: Harcourt Brace Jovanovich Gollege Publishers.

Udlændinge-, Integrations- og Boligministeriet (2016a) Resultater af afdækning af flygtninges kompetencer [Results from the disclosure of refugee's competences]. www.uibm.dk.

Udlændinge-, Integrations- og Boligministeriet (2016b) Orienteringsskrivelse om ændringer af integrationsloven m.v. som følge af vedtagelse af lovforslag L 189 i Folketinget den 3. juni 2016 [Information letter about changes in refugee legislation etc. as a concequence of the passing of law proposal L189 in the parliament June 3rd 2016]. http://uim.dk/filer/ integration/orienteringsskrivelse-1-189.pdf .

\section{Notes}

${ }^{1}$ For example: https://www.dr.dk/nyheder/politik/loekke-flygtningekrise-udfordrer-danmarks-vaerdier, https://www.bt.dk/danmark/overblik-det-er-der-sket-siden-flygtningestroemmen-ramte-danmark, or https://www.fm.dk/publikationer/2016/et-staerkere-danmarkflygtningestroem

2 http://borsen.dk/nyheder/generelt/artikel/1/117461/danmark $\mathrm{i}$ front med ingenioermangel.html https://www.electronic-supply.dk/article/view/223832/ingeniormangel i 7 ud af 8 beskaeftigelsesregioner\# http://finans.dk/artikel/ECE4218650/Firmaer-misterordrer-p $\% \mathrm{C} 3 \% \mathrm{~A} 5$-grund-af-ingeni $\% \mathrm{C} 3 \% \mathrm{~B} 8 \mathrm{rmangel} /$ ?ctxref=ext

3 The project was supported by the Confederation of Danish Enterprise (Dansk Erhverv), the Confederation of Danish Industry (Dansk Industri), the Danish Plastics Federation (Plastindustrien), as well as with letters of intent from a number of large companies and SMEs.

${ }^{4}$ For critiques see Shove 2010, Reckwitz 2002, Schatzki 2002.

5 Theodore Schatzki $(2002,146)$ general definition of a 'site' is '... a context, some or all of whose inhabitants are inherently part of it'. More specifically, Shcatzki $(2005,467-8)$ states that "'Sites', as I use the them, are arenas or broader sets of phenomena as part of which 
something - a building, an institution, an event - exists or occurs'. Sites are thus meshes of arranged things and organized activities. Semantic 'things' (the language and discourse we use), the material 'things' we are surrounded by, and the social 'things' (e.g., social groups and relationships) enable and constrain what we do (cf. Kemmis et al. 2014, 29).

${ }^{6}$ In early September 2015, the Danish government ran official anti-migration advertisements in a number of English and Arabic newspapers in Lebanon. In them, the Ministry of Immigration, Integration, and Housing listed reasons why Denmark would be an undesirable destination for refugees. For more information: https://www.washingtonpost.com/news/ worldviews/wp/2015/09/07/denmark-places-an-advertisement-in-lebanese-newspapersdear-refugees-dont-come-here/?utm term=.de1b5fb097dc and: http://www.bbc.com/news/ world-europe-34173542

7 https://www.industriensfond.dk/arbejdskraft

$8 \mathrm{KL}$ - Local Government Denmark is the association and interest organisation of the 98 Danish municipalities. All 98 municipalities are voluntary members of KL. KL secure the interests of the municipalities, consult individual municipalities, and disseminate relevant information. 